\title{
Galactoside-Binding Soluble Lectin 13
}

National Cancer Institute

\section{Source}

National Cancer Institute. Galactoside-Binding Soluble Lectin 13. NCI Thesaurus. Code C101557.

Galactoside-binding soluble lectin 13 (139 aa, $16 \mathrm{kDa}$ ) is encoded by the human LGALS13 gene. This protein is involved in lysophospholipase activity. 